\title{
TOWARDS EMPOWERING ZAKAT RECIPIENTS: AN ASSESSMENT ON EFFECTIVENESS OF ZAKAT INSTITUTIONS FROM THE ZAKAT RECIPIENTS' PERSPECTIVE
}

\author{
Norazlina Abd Wahab', Md Mahmudul Alam², Ashraf Al Haq ${ }^{3}$, Suraiya Hashim4, Zairy Zainol ${ }^{5}$ \\ 1,3,4,5Islamic Business School, Universiti Utara Malaysia \\ ${ }^{2}$ School of Economics, Finance and Banking, Universiti Utara Malaysia
}

Received: 20.05.2020

Revised: 17.06.2020

Accepted: 04.07.2020

\begin{abstract}
This study aims to investigate the effectiveness of zakat institutions from the zakat recipients' perspective. Researchers opine that empowering is a matter of utmost importance in order to ensure recipients are self-sufficient, self-reliant and can withstand any hardship come it may. Therefore the zakat authorities need to safeguard a robust empowerment regime and for that reason the assessment of that performance may require a newer dimensional approach where 'the recipients' who are the main stakeholders do evaluate the contributory performative assessment through the main four perspectives as enshrined by the Balanced Scorecard technique which include financial effectiveness, customer effectiveness, internal effectiveness and learning \& growth effectiveness. Hence, the goal is to investigate the effectiveness of zakat institutions of Kedah, Malaysia in particular. A total of 427 responses received, where Partial Least Squares approach was employed as the main data analysis of this study. The research identified that all the four components are interlinked and need a coherent addressing in terms of zakat recipients' upliftment. The recipients did put emphasis on the priority of the financial effectiveness, but in a non-profit environment where the customer effectiveness is vital, may require the service enhancement along with putting the emphasis on learning and making certain systematic rejuvenation of the processes, as well as the planned financial decision to make effects conducive to empowerment of the recipients.
\end{abstract}

Keyword-- Balanced Scorecard, Effectiveness, Empowerment, Zakat, Zakat institution

(C) 2020 by Advance Scientific Research. This is an open-access article under the CC BY license (http://creativecommons.org/licenses/by/4.0/) DOI: http://dx.doi.org/10.31838/jcr.07.08.313

\section{INTRODUCTION}

In the drive towards empowerment of zakat recipients, the current emphasis is rather on action than mere words. Furthermore, the literature in its development is very wide and but marginally debatable. The reason is, since very beginning the researchers did identify the important gap of 'empowerment' that has been unknowingly missing in general zakat giving, but lately many recent authors proclaiming that 'it' is on the move, but the ground reality is, it is still bit not that supportive to asnafs' (zakat recipients) overall condition as well as drive towards genuine upliftment and sustainable welfare. Therefore, a need arises to understand the reality in true sense and hence the present research aims to assess and understand the recipients' perspective in drive towards empowering them, where their valued inputs will determine the magnitude of the true development in the empowerment arena. It is intended to understand as well as appreciate the zakat's institutional development and performance through the understanding of the wellbeing issue of the zakat recipients, and if the issue is well addressed and the wellbeing 'is' noticeable - only then it will nonetheless indicate that the institutional performance is well adhered, and the institutions are responding to the needs and wellbeing of the recipients.

Bakar et al. (2011) though posit that the self-sustaining, selfempowering method of zakat management could be most effective for the asnaf development, but before embarking on that noble mission, the authors such as Ahmad et al. (2017) acknowledge the missing gaps of customer service satisfaction in zakat management. The authors highlighted the importance of zakat's service provision that are necessary in reducing the inequality, and increasing the ability, through capacity building, as visualised by Ab Rahman et al. (2012).

In addition to customer satisfaction, the importance of financial dimension is equally significant. The authors (Ahmad et al., 2017), states that zakat has the potential of having strategic importance in the world of 'Islamic finance' and is rated as the most 'critical instrument' in a developing economy, which in other words to purify and sanctify one's wealth (Al Qur'an 9:103), that can help in societal development through the proactive and effective empowering assistance. The process in retrospect assists in reducing the income inequality gaps over time to a significant extent that exists in society.

Thirdly the internal development dimension is equally paramount in ensuring unhindered empowerment in the drive towards the recipients' welfare. In Ahmad et al. (2017) explanation, empowerment through zakat, can supplement and enhance the comfortable living in broader sense. Because the benefits of effective management (internal development), will enhance service quality, and that in turn will broaden the collection, distribution and beyond - to soothe the relationship as well, between the haves and the have-nots. In actual fact, ensuring the wellbeing of the recipients, does make in-depth sense in effective giving, and that as well is in conformity with Maslow's theory of human development (Bakar et al., 2011).

But above all, the skills development and knowledge enhancement in empowerment strategy would make the recipients become more up-to-mark to combat poverty directly and be resilient in dimensional change. Ab Rahman et al. (2012) explains in plain terms that though short-term cash hand-outs are important for subsistence, but focusing on long-term empowerment and skills enhancement is vital for proactive and effective economic development and growth in the nation. In same breath, Yusoff (2008) emphasised the need for implementing the long term policy approach along with the shorter one. According to the said author there is dire need to educate the receivers in line with human capital development so that these zakat receivers can have self-sustaining development in the longer run. Though there are asnafs who will be in continuous need bracket due to health or age issues, but the vast majority must be reoriented so as to survive through new skills 
enhancement. In authors own words, the receivers need to learn 'how to catch fish rather' than 'provide them with fish to eat'.

Researchers are of the opinion that a performance measurement as well as a performance management system (PMS) is important, to address the intricacies of different bottlenecks in customer satisfaction, internal rejuvenation, learning enhancement and having a balanced and progressive financial as well as non-financial assortment, that will ease and energise the zakat institutions to deliver optimum satisfaction to both the customers, i.e. the receivers and givers of zakat, who are paramount in passive decision making and interlinked through optimum zakat management (Taha et al., 2014; Zakaria, 2014; Zulkifli et al., 2014).

Noor et al. (2015) point to the importance of multidimensional performance assessment to understand the significance of timing, cost and the quality of zakat's distributive management in terms of effectiveness. It is necessary to measure performance through 'a process approach', as per the said authors. A detailed analysis that was conducted by authors identified that the necessity of adequate resources are required to ensure timely and improved distribution to meet the institutional goals. To achieve that, the authors proposed the need for benchmarking to critically assess customer requirements. Because this 'process approach' will detect the gaps in performance and will subsequently help to improve the system successively. The authors state that despite inputs, the outputs and process play a role in assessing performance, and these output results are truly important for the non-profit stakeholders, because they are crucial for the growth of NPO and its wide possibilities.

In accepting the need for eloquent management in zakat sphere, Mujiatun (2018) elaborates the need for constructive upliftment of the deficit group (mustahiq) to make them a surplus group (muzakki) in the course of time. But in that drive, all the stakeholders need to appreciate the benefits of effective zakat management that may bring stability and positive implications even in after life along with worldly comfort. This emphasis on hereafter distinguishes the understanding of the conventional norm with the Islamic comprehensive fiscal measures. Therefore, this wide-ranging stressing will ensure better effective measures in management and distributive aspects and that may likewise ease the tasks in grasping the benefits here and hereafter. To achieve to this very end, all the stakeholders, like human, natural, information, financial, planning, partnership, modern sector exploration need to be in coherent order to foster public trust and confidence in regaining this zakat sector.

\section{LITERATURE REVIEW}

Reviewing the Balanced Scorecard (BSC)'s Implications in the Zakat Literature

According to Dale MacKrell et al. (2011) and other authors who are concerned in non-profit organisations (NPO) development, do suggest that BSC could be best suited to augment the issues in NPO. Kaplan (2001) proposed a revised BSC framework specifically for the NPO, where customers' perspectives become more imperative than profit aspects.

Niven (2002) further explains that the BSC is actually a very proactive feedback based management system that rejuvenates the internal business processes and coordinates coherently the external outcomes in order to continuously improve strategic performance and results. When BSC is fully deployed, it will transform strategic planning from an academic exercise to the nerve-centre of an enterprise (balanced scorecard, n.d). As most researchers in zakat, wants the zakat institutions to perform taking into account the perception of all the stakeholders, hence the implementation of this BSC management system can be resultantly a robust way forward (Fadilah et al., 2016; Taha et al., 2014; Zakaria, 2014; Zulkifli et al., 2014).

In BSC, the non-financial measures such as customer perspectives, internal business processes and learning-andgrowth combined with financial perspectives, analyses the organization's true outcomes (Masyita, 2012). Moreover, the learning and growth perspective in particular, institutes meaningful success because of skills enhancement (Sureshchandar et al., 2005). Therefore, Kaplan and Norton repeatedly emphasised that 'learning' is actually more than 'training'. In reality, BSC adds value to organisations, as it provides balanced information (Van Der Zee et al., 1999) and provides a strategic planning option to perform as well as create an advantageous learning atmosphere in the organisation. In the end, the process relies on both formal and informal methods to achieve a desired success (Mooraj et al., 1999).

According to Kaplan (2001) in the NPO, the issue of accountability and performance measurement has gained importance, due to stakeholders' perception on satisfaction. Unfortunately, the yearly-financial-report that is produced conventionally only emphasises on the financial performance, which may lead to non-comprehensive strategic decision. Kaplan (2001) explained that the success for non-profits needs to be measured by how effectively and efficiently all the sectors meet the needs of their stakeholders. Financial deliberations can play a constraining role but in most NPO cases it cannot be the primary objective. The reason being, in NPO it's the customers, as the prime stakeholder and its concern need more attention than any other matter. In a profit entity, the prime objective can be the financial achievements, but in NPO it will most likely be the customer or any defined objectives, like poverty reduction or so on. Hence in NPO, the priority remains customer centric surpassing the financial one.

Zakaria (2014) discussed the importance of implementing the BSC framework to assess the effectivity of zakat management. In the findings, it became noticeable the impact of knowledge i.e. the learning and growth perspective that played the role of prominence. According to the said author, the issue of effective distributional management is the main concern so far. The justification of using the BSC framework according to the author is that the human needs is not only confined to monetary needs, but includes the non-monetary elements likewise. In pursuant to this, in the drive towards self-development and selfempowerment - acquiring knowledge becomes vital to maintain long term contentment (Zakaria, 2014). The author understands that treating wealth as God's valued and gifted trust, and this belief will allow the recipients and givers to remain content and be gratified to lead a hale and hearty life.

While explaining the zakat's distributive effectiveness, Zakaria (2014) clarifies that assessing the performance of a programme initiated by zakat institution in meeting its defined objectives is key, and this effectiveness can be positively evaluated by Balanced Scorecard as explained by Norton and Kaplan (1996). According to Zakaria (2014), not only the financial performance of the programme is important, but likewise other measures are equally vital, and that can be attained through the BSC adoption as a measuring tool and managing it accordingly. Therefore, Zakaria (2014) proposed a dynamic model of BSC for zakat's distributive effectiveness, which is correspondingly important for the present study. The author conducted the study in Kelantan, and duly suggested numerous recommendations for forthcoming research options and also the importance of developing the complete BSC framework for the zakat institutions. 
Highlighting the lively points on BSC, Taha et al., 2014 pointed that BSC is driven by strategy and vision and not solely on exerting unnecessary control. After applying the BSC, the planning, measuring, monitoring of desired outcomes remains the essentials to attain the anticipated goals and objectives that were naturally set at the very beginning. When the entire organisation follows 'a set strategy', the outcome is assumed to provide a better result, if inappropriately the implementation is not deprived of continuous re-evaluation and realignment as needed in any BSC framework (Taha et al., 2014).

But according to Taha et al. (2014), BSC has hardly been widely discussed in Malaysian zakat context. According to the said authors, as collection, distribution and the contributory factors are resounding upwards, the prudence towards the judicious application of the BSC techniques or similar, needs careful look through, though. Hence if the BSC is adopted by zakat institutions in disciplined manner, then the perception and outcome in effective notion in the area of zakat's institutional empowerment may improve. This will be a worthy conception in terms of fulfilment and attainment. Therefore, implementing the BSC framework sensibly may provide the desired sustainability structure to the zakat institutions, because the correct implementation will ensure the efficient and effective institutional development. And in turn, it will be a case of perceptible development in line with effective empowering distributive management of the limited zakat funds in uplifting the designated zakat recipients (Taha et al., 2014).

While reviewing the BSC framework, Taha et al. (2014) highlighted the significance of the system, which incorporates the comparative analysis, objectivity revision, understanding the lagging and leading issues in measurement techniques and the salient indicators, and the internal and external considerations in performance measurements. And similarly, the need to look into the ways to focus on short, medium term and long term objectives of the NPO that may require careful observation (citing Martinsons et al., 1999). So proper execution of the BSC method in actual fact can balance the benefits over costs and that can be a momentous aspect for zakat institutions to have a better outcome in the areas of lagging factors.

In the same breath, Taha et al. (2014) highlighted the prominence of financial measures in ensuring optimum allocation of resources, and that will ensure the maximisation of the customer satisfaction factor as well as value creation in the strategic inventiveness. According to the said authors, customer perspective on satisfaction issues is the most significant in understanding the BSC's importance in NPO. Therefore, this contentment aspect will lead the internal factors to be tailored. And equally, that will bring the effectiveness and efficiency in the internal system by addressing the customers' perspectives as the main driving force, and such marvellous accomplishment is only possible through the strategic arrangements of the required assets and objectives.

Hence, to ensure the success in internal factors, the everdeveloping learning and growth curve will put an emphasis on specifically the employee retention, their satisfaction and that in return may assist in improving the productivity, which will drive the BSC cycle to fulfil the zakat institution's stated objectives. And such phenomenon will magnify the shared dream and improve the perception from all perspectives, as can be agreed from Taha et al. (2014) elucidation. This learning will let the technology, employee and the organisational management be a one unique entity - gratifying the defined corporate strategy.

Similarly, Zulkifli et al. (2014) tried to ascertain the effective as well as the efficient Zakat management mechanism and identified the satisfaction level of the recipients by implementing the Balanced Scorecard (BSC) approach along with the religiosity perspective as the fifth element in the analytical design. The authors rightly acknowledged the need for effectiveness in the system, and that is what was endorsed after analysing the data. The responses from the survey questionnaires further ascertained the degree of dissatisfaction by the zakat recipients towards the distributive wisdom, so the authors were not that enthusiastic by the amount that is left undistributed year after year (of the collected funds). The authors similarly raised the issue of timeliness issues. These untoward issues may necessitate careful addressing and consideration by future researchers and policy makers, as improvements in the institutional management as well as in the distributive system is necessarily required to gain resilience towards the welfare initiatives and policies.

Zulkifli et al. (2014) highlighted that BSC as a measurement tool of zakat institutions may be best matched given the importance given in the NPO and zakat literature. The authors state that, BSC is exceedingly suitable for multidimensional performance evaluation that can be properly applied in Zakat institutions in order to assist the 'effectiveness and efficiency of Zakat distribution'. Furthermore, Zulkifli et al. (2014) objectively pointed out that the zakat needs to be effectively managed and the recipients need to be correspondingly pleased.

Financial Effectiveness and Empowerment in Zakat

Rachman et al. (2018) proposed a zakat based financial technology which integrates the zakat management system to provide optimal services to its consumers. The authors further urge for reinforcement the technology-based management system especially for zakat to ensure better utilisation of the fintech media. This innovated information based fin-tech is a heightened instrument for the social finance sector, such as zakat management, and has a prospect of implementation beyond territories, in terms of adequate collection and timely and effective distribution of the limited zakat funds.

Othman et al. (2018) and Saad \& Farouk (2019) state that Zakat could play not only the potent role of Islamic public finance but also as a dynamic mechanism of income re-distribution, and likewise as a necessary device for poverty alleviation. During the pious caliphates time, the economic management was such that it was obvious that the seekers of zakat were quite negligible (Nadzri et al., 2012; Saad et al., 2016). Moreover, Nadzri et al. (2012) acknowledged that often direct payments or cash handouts may not provide incentives (except in when it's necessary) towards productivity, therefore empowerment option can be effective and proactive to uplift the receiver where he or she is encouraged to do more, and educate him or herself in sustainable method of a long term survival without seeking any help further. In this way the zakat's distributive gratification level will improve and the transparency factor will be enhanced.

Afandi (2019) explains the process of wealth purification through the mean of obligatory zakat payment to mustahik (the zakat receiver) by the owner of wealth, the muzakki. The progression does not stop at distribution only, but ensuring in the course of time that the receiver becomes zakat giver soon, and equally helps in poverty reduction in the economy.

Khairunnajah et al. (2019) duly reported the reduction in the incidence of poverty in rural Indonesia due to proactive zakat empowerment by the state zakat authority (BAZNAZ). The salient feature of community development is noticed where capital for farming, trading, and similar were sanctioned, and that augmented the condition of the zakat receivers suggestively. Remarkably and resultantly, the material, religious and other 
needs are markedly fulfilled and the entity's strategic body's careful and timely assessment and assistance, continuously enriching as well as improving the overall situation at the receiving end, and that is a very commendable development as per the said authors.

While prompting zakat's growth possibility in the realm of productivity, Ibrahim et al. (2014) upheld that zakat can be a way forward towards empowerment and helping the asnaf through micro-financing of the zakat funds, and that may be the most permissible way of alleviating poverty and reducing the income gap. The authors accept zakat's expansion and growth potential as business capital. Besides, the authors share the view that creating business capital at times through conventional banking system may be cumbersome for the poor masses, so if the zakat fund can be utilised for economic liberation of these hard-earned population, would be a great revolutionary way forward.

Ahmad et al. (2012) emphasised the importance of zakat's distributional management aspect, and further examined the investment features of the zakat funds. Besides, the allocative efficiency of zakat resources has two effects, one on incentive and the other on employment enhancement (Ahmad et al., 2012). Due to punitive zakat tax on idle money, the influx of investment generation in the economy will spur growth and employment; thereby moving a sluggish economy to perform better towards economic growth and social development (Ahmad et al., 2012). Therefore, zakat can play along with poverty alleviation role - the investment role, to mend the long term social ills in society (Saad \& Sawandi, 2016).

The authors (Ahmad et al., 2012) further posit that the poor and needy in fact require such zakat investment assistance, and such support and careful monitoring will help the needy to be on the rise, as inappropriately they are subjected to frequent financial exclusion and often remains in that 'exclusion' bracket because of less skills and opportunities, less resources, less (insider) information and less knowledge compared to society's elite at large. Therefore, this guarded and timely zakat assistance is supposed to enhance the poor zakat recipient's - human, financial, social and physical capital requirements and will make these ill-fated citizens to compete in survival techniques to win in life, as per Ahmad et al. (2012) meticulous elaboration.

Said et al. (2014) carefully investigated the asnaf by segregating male and female orientation towards the entrepreneurial aspect, product and service innovation, financial management and marketing strategy. The results of the study are actually in line with previous studies, and this is an important benchmark for future zakat developments and specially for the zakat institution to ponder for right step forward and the right mode in terms of assistance, planning, shaping, strategizing, executing, monitoring and budgeting for upcoming empowerment plans towards a more harmonising and sustainable development of zakat recipients and thus to ensure effectivity in zakat distribution. Unfortunately, the failure rate (in asnaf empowerment strategy) of seventy seven percent is way too high compared to world average. On further recommendation, the authors asked for careful analysis of each recipient asnaf in terms of their positive attitude, capability and skills matching technique, so that the fund is effectively utilised and maximum gain received.

\section{Customer Effectiveness}

So the present study is intended to look into the possibility of findings what are the gaps in the area of effective institutional factors, as this issue has gained momentum and has become a great concern for the Malaysian researchers, because the increment in collection is based on customer's undivided perception of transparent and commendable zakat distribution
(Jaffri Saad et al., 2010) as well as management towards wellbeing of the zakat recipients (Ab Rahman et al., 2012; Bakar et al., 2010). It is noteworthy to mention that in not-for-profit ((NFP or NPO in literature) organisational studies, the customers' trust factor remains the focal point of any meaningful expansions (Buckmaster, 1999; Gray et al., 2006; Greiling, 2007; Yap et al., 2010). Customer perspective has the vital role in NPO studies, as per Kaplan (2001).

The reason is, to be customer friendly is an important aspect in gaining customer loyalty towards achieving the asnaf welfare (Bakar et al., 2014; Hassan et al., 2005; Tajuddin et al., 2014). This customer dimension is important in both the receiving and giving ends, as both are intertwined. Nonetheless, the effectiveness depends on providing the necessary zakat amount at the right time, and likewise receiving the necessary contribution from the zakat giver at the right hour, and that way the cycle may have a better flow.

Furthermore the issue of customer satisfaction in zakat has been empirically tested by the following researchers (Mohit et al., 2011; Muhammad et al., 2015; Noor \& Saad, 2016; Yusof et al., 2013, Zainal et al., 2016). The issue is of importance primarily owing to - whether the giver is happy giving the due, and next whether the receiver is happy in receiving the amount. And not to ignore, that the satisfaction in collecting as well as distributing the alms by the amil or any distributer as it may be, is equally important as it gives ease to the arduous process (Zaenal et al., 2014)

Authentic caring in ensuring client satisfaction (Idris et al., 2013; Ghazali et al., 2016; Tlemsani et al., 2013; Zsolnai, 2015) is often related to adequate training (Clark, 2001; Hassan, 2010; Hassan et al., 2012; Muhammad et al., 2013; Yusoff et al., 2012). And this precise training will assist staff to follow guidelines diligently (Abdullah et al., 2013; Akhyar Adnan et al., 2009; Bakar, 2007; Farrukh, 2016; Ibrahim et al., 2012; Mat, 2008; Mohammad et al., 2015; Noor et al., 2011; Othman et al., 2012; Puad et al., 2015; Raquib, 2011; Richardson, 2004; Sulaiman et al., 2014, 2015; Toor et al., 2004). But customer care essentially encompasses both the service quality and the vigilant control (Adnan et al., 2013; Kaslam, 2009; Lubis et al., 2011; Nadzri et al., 2012; Wahab et al., 2011). In other words, the learning and growth perspectives as feted by Norton and Kaplan (1992) may revitalise the internal processes, such as service quality and that may lead to enhanced customer care, as envisioned by above mentioned researchers.

Zulkifli et al. (2014) identified the dissatisfaction in the distribution mechanism, and hence suggested that to overcome the zakat's contributory issues, the system needs to adopt a more healthier approach in terms of customer transparency, accountability processes and so on. The study further highlighted the issue of huge zakat fund each year that is left despondently undistributed. The authors moreover identified that the excess of zakat collection in 2011 and in 2012 were RM 253 Million and RM 336 million respectively, which demonstrates a huge disproportion in terms of zakat's distributive effectiveness as well as raises the issue of managerial efficiency in executing the blessed task. In authors own words, "The public and the stakeholders are left unsure whether their contributions are distributed to the qualified eight asnaf. This leads to the negative perceptions by the recipients and others on the management of Zakat institution" (Zulkifli et al., 2014).

Zulkifli et al. (2014) further identified that the issue of effectiveness or at times inefficiency in the administration, is owing to undue care in professional recruitment policy of the zakat institutions. This unprofessionalism gives rise not only the 
ineffectiveness, but other related factors and issues that often cripples the smooth management, and more so the customer retention and satisfaction. This further incapacitates the assurance level amongst the contributors, and the information of undistributed zakat amount not shared to the public is an added blow to the reputation of an important NPO entity.

According to Abioye et al. (2013), zakat is an emerging sector, so understanding the importance of trust, honesty, effectiveness and efficiency by the zakat authorities and policy makers - is important for the revival and survival of this sector. Furthermore, according to Senadjki et al. (2015) just distributing zakat may not be fully effective in terms of poverty alleviation, if the intention to be out of that trap is not present in the 'self' of a zakat recipient. No matter how much the zakat system helps or other mechanism tries to remove a person from hardship, if the asnaf is not thoughtful enough in appreciating the magnitude and respecting the will of society in terms of understanding the curse of poverty and alike, then all the efforts by any zakat authority may not be visualised due to the lack of intent from the asnaf to be self-sufficient, self-reliant as well as to be a progressive entity in the society. Senadjki et al. (2015) believe that the Prophetic (PHUH) warning regarding understanding the self-respect is paramount in removing the poverty issue in society.

Senadjki et al. (2015) further quoted a famous hadith narrated by the Holy Prophet (PBUH), and reported by Abdullah ibn Umar (RA). The Prophet (Peace be upon him) explained that each of us is like a shepherd and each of us is responsible. The ruler is a shepherd and responsible for his flock. A man is the shepherd of his household and responsible for his family. A woman is the shepherd of her husband's house and children and responsible for her family. The slave is the shepherd of his master's wealth and responsible for it. Each of us is a shepherd and each of us is responsible for our action (Sahih Al-Bukhari No 6719; and Sahih Muslim No 1829).

In the book written by A K Sen in 1981 on cause of poverty, famines and deprivation, the writer explained that in the subject of famine, the issue is lack of accessibility and not the issue of inadequacy. Therefore, the authors (Senadjki et al., 2015) invalidates the concept of scarcity, and feels that Muslims need to strive harder by making efforts to self-sufficiency, and also in addition, Allah commands the believers in the holy scriptures, "And your Lord says: call upon me, I will answer you" (Al Qur'an 40:60).

Wahab et al. (2016) presented a robust framework on service quality index that best suits for zakat institutions. Ill-advisedly, the issue of giving zakat direct to the recipients by the sahib-enisab (givers) bypassing the authority negates the purpose of setting up the organised institutions, and it's quite challenging to enact a tenet that a giver cannot and should not do so (meaning bypassing the zakat establishment in principle). Hence as a result, 'only' guaranteeing the excellence in service and the very desired quality (Wahab et al., 2016) will ultimately make these providers and givers of zakat to utilise the right channel in addressing the woes in society through reverting to, as well as appreciating, the institutional remedy that is before them.

\section{Internal Effectiveness}

While perceiving the internal issues in zakat spectrum, Lubis et al. (2011) highlighted the pointless cumbersome processes of delaying in promptness in the zakat distribution, and that unfortunately gives rise to further debates and worries, and hence such tardiness may not help to solve the hardship issue as expected by many. In fact, this hardship reduction was targeted as the prime objective by the zakat authorities (Saad et al., 2014). Abdulai et al. (2014) admit that institutional factors such as capacity building, income generating policies and other proactive action plans, such as promoting publicity, encouraging collection through appointed authorised departments, building institutional confidence and so on are the measures that can reshape the zakat scenario.

Ab Rahman et al. (2012) relies on the notion that zakat as a safety-net remedy to avoid recessionary pressure can be a welcoming episode to lessen the adverse impacts in a zakat-able economy because of inherent potentials of building the capacity and likewise furthering the prospects of transformation of the mind-set in the very receiving ends. The authors similarly believes that the effectiveness of zakat empowerment depends on proactive resource expansion, improving the collection base from both tangible and intangible sources, strategic build-up of systems in the zakat institutions, and ensuring socio-economic reforms to address the possibilities of zakat assistance in the drive towards long term effective hardship reduction. Ab Rahman et al. (2012) believe that the brotherhood injunctions that was ordained from the Lord Almighty to look after 'in time of need' by 'able bodies' (Al Qur'an 49:10) are equally a paramount factor in addressing the woes and uplifting the status-quo.

\section{Learning and Growth Effectiveness}

To overcome the poverty and hardship, zakat institutions require to focus on intellectual capital development (Adnan et al., 2013), which is also the main emphasis by all the leading management enhancement frameworks, such as BSC. According to Adnan et al. (2013) to realise zakat performance as expected, the modern paradigmatic change and development embraces the intellectual innovativeness, skills development and learning capabilities as the main driving force in place of tangible or financial capital. The financial or other tangible assets given at times are limited, but the knowledgeable enhancement capabilities for the staff or recipients are essential for getting the best outcome.

At occasions, fund shortage may not allow easy and worthy zakat distribution (Saad et al., 2017). But if the limited fund can be effectively utilised as skills enhancement, or may be through improved management system (Lubis et al., 2011), then the performative attainment by these noble Non-Profit Organizations (NPO) may tilt the entire scenario, and make the concerned asnaf and the zakat contributor viably cheerful, as witnessed in Sudan (Abdelmawla, 2014). To this developing end, Ahmad (1991) and Sawandi et al. (2017) maintain that only effective and just management of the zakat fund is a true contribution to social welfare. Hence through appropriate advice and necessary knowledge enhancement - the status of asnaf can be noticeably changed, as was witnessed in case of Sudan (Abdelmawla, 2014). The author stated that importance of knowledge enhancement should supersede just mere cash handouts, as has been empirically viewed in Sudanese experience. The authors (Adnan et al., 2013) emphasised that to avoid incompetency or issues related to service quality, or such as lethargic performance and so on, the implementation of intellectual capital growth as well skills development is significant as that will deter ineffectiveness as was seen in a comprehensive Greek study done by Cohen et al. (2013) as reported by Adnan et al. (2013).

In his empirical study, the author (Abdelmawla, 2014) did a head count index, which was the function of 'the percentage spent on poor out of total zakat funds' and 'educational attainment rate'. Put simply, the model is, $\mathrm{H}=\mathrm{F}(\mathrm{Z}, \mathrm{E})$ correspondingly. The results showed that educational attainment led to decrease in hardship in a far better way than just financial assistance rendered. Concomitantly, the education development is viewed by zakat authorities as important priority in nation building (Hassan et al., 2016). Therefore, it is suggested that the zakat institutions need to reemphasis on developing this 'particular' education sector 
from pre-school till tertiary level, as was equally witnessed in case of Selangor zakat (Haron et al., 2010).

\section{THE RESEARCH METHODS}

\section{Primary Data Collection and Descriptive Statistics}

The study is basically based on primary data. The data is collected through a structured questionnaire survey. 427 samples were collected through stratified random sampling technique from eleven zones of Kedah. Few enumerators were tasked to assist in data collection. The reason for choosing such a big sample from wider Kedah is to get the detailed outlook on recipients' perception and understanding on the ground reality. Over a three-month period data was collected, nearly 440 questionnaires were distributed and 427 responses were received, generating a response rate of nearly 97 percent. Out of which about 47 percent are male and the rest are female. And closely 57 percent are from 40 to 60 age bracket, in other words confirming the active age for empowering themselves. Furthermore approximately sixty percent that responded were married, and nearly 46 percent had primary and 42 percent secondary education. And below three members in the household consists almost 72 percent of the respondents. Number of earning member less than one is about 78 percent, and receiving zakat less than RM 500 monthly is nearly 75 percent, and out of total respondents more than half is rather new or less than a year zakat applicant.

Table 1. Respondents' Demographic Profile

\begin{tabular}{|l|l|l|l|}
\hline Variable & Detail & Total & Percentage \\
\hline Gender & Male & 203 & 47.5 \\
& Female & 224 & 52.5 \\
\hline Age & $20-39$ & 48 & 11.2 \\
& $40-60$ & 244 & 57.1 \\
& Above 60 & 135 & 31.6 \\
\hline Marital status & Married & 260 & 60.9 \\
& Widow/Divorced & 146 & 34.2 \\
& Single & 21 & 4.9 \\
\hline Education & No education & 47 & 11.0 \\
& Primary school & 19 & 45.4 \\
& Secondary school & 175 & 41.0 \\
& Certificate & 7 & 1.6 \\
& Diploma & 2 & 0.5 \\
& Degree & 2 & 0.5 \\
\hline Earning members & 1 or less & 331 & 77.5 \\
& 2 a & 68 & 15.9 \\
& 3 & 21 & 4.9 \\
& 4 & 5 & 1.2 \\
& 5 and above & 2 & 0.5 \\
\hline Household income & $0-500$ & 185 & 43.3 \\
& $501-1000$ & 159 & 37.2 \\
& $1001-1500$ & 68 & 15.9 \\
& $1501-2000$ & 10 & 2.3 \\
& More than 2000 & 5 & 1.2 \\
\hline Household earnings from & $0-500$ & 319 & 74.7 \\
zakat & $501-1000$ & 84 & 19.7 \\
& $1001-1500$ & 22 & 5.2 \\
& $1501-2000$ & 1 & 0.2 \\
& More than 2000 & 1 & 0.2 \\
\hline
\end{tabular}

In table 2 below, the purpose of seeking zakat by recipients is given and it can be observed that nearly forty-eight percent seeking zakat just for food, and if it is analysed delicately, it seems that just food survivability is the main concern of nearly eighty plus percent of the total. For business expansion, it is just nearly five plus percent in total, thereby puts the very questions of the possibility of long term survivability without the cash hand-outs.

Table 2. Purpose of seeking zakat by recipients

\begin{tabular}{llll}
\hline SL & Purpose of Seeking Zakat & Frequency & Percent \\
\hline 1 & Schooling & 15 & 3.51 \\
2 & Food & 203 & 47.54 \\
3 & Food \& schooling & 30 & 7.03 \\
4 & Food \& Business Capital & 12 & 2.81 \\
5 & Food \& Housing expenses & 15 & 3.51 \\
6 & Food, business capital \& housing expenses & 5 & 1.17 \\
7 & Food, medical \& schooling & 96 & 22.48 \\
8 & Medical & 29 & 6.79 \\
9 & Food, medical expenses \& business capital & 3 & 0.70 \\
10 & Business capital & 19 & 4.44 \\
\hline
\end{tabular}




\section{Questionnaire Design}

The questionnaire for the study is designed to collect data for empirically testable parameters. The questionnaire has different subsection like customer satisfaction, internal effectiveness, learning opportunities, financial wellbeing and perception on zakat efficiency parameter as identified by the recipients. The literature above has brief explanation regarding the parameters.

Variables are evaluated using a 5 point Likert-scale to illustrate their degree of agreement. Scale point " 5 " indicating "strongly agree", and follows other remaining scale point until point " 1 " for "strongly disagree".

\section{Data Analysis}

In this study, the primary data is analysed mainly by preparing an index under BSC performance measurement. Moreover, this study uses structural equation modelling (SEM) and descriptive analysis. The study also utilises different software such as SPSS, SMART PLS, MS Excel, and MS word.

\section{RESULTS}

The mean, standard deviation, composite reliability, validity of the construct, discriminant validity, Heterotrait-Monotrait Ratio HTMT are given below. Average variance extracted AVE is a measure of convergent validity and of error-free variance in a set of items, and discriminant validity or divergent validity tests the extent of non-relation of the measurements (Campbell et al., 1959). The composite reliability CR and the Cronbach's Alpha CA need to be greater than 0.7, according to Hair et al. (2014), and AVE should be above 0.5 . The CR values are above 0.9 , CA more than 0.7, and AVE is above minimum threshold, thereby fulfilling the criteria in the results below, and the constructs have achieved internal consistency (reliability) and convergent validity. Since the CR and AVE maintained the threshold, it is not necessary to remove any of the items used in the model.

Table 3. Mean, Standard Deviation, Reliability, and Validity of the Construct

\begin{tabular}{lccccc}
\hline & Mean & SD & Cronbach's Alpha CA & CR & (AVE) \\
\hline CE & 4.217 & 0.762 & 0.919 & 0.937 & 0.713 \\
FE & 4.244 & 0.703 & 0.928 & 0.943 & 0.736 \\
IE & 4.157 & 0.686 & 0.905 & 0.928 & 0.683 \\
LGE & 3.955 & 0.770 & 0.871 & 0.900 & 0.601 \\
\hline
\end{tabular}

Where CE is customer effectiveness, FE financial effectiveness, IE internal effectiveness, LGE learning and growth effectiveness, CR composite reliability, AVE average variance extracted

The discriminant validity and HTMT ratio is given below. Assessing the cross-loadings through Fornell Larcker criterion is equally important for estimating discriminant validity, as per Henseler et al. (2015). Rendering to the said authors, Fornell and Larcker criterion is validated if a latent variable has more variance than its associated indicators.

In other words, the squared root of the AVE needs to be higher than each of the construct correlations, in the Fornell-Larcker F\&L criterion (Hair et al., 2014). The results below are indicative that F\&L criterion is fulfilled. Furthermore, according to Henseler et al. (2015) the HTMT ratio is seen as a better option compared to F\&L criterion, therefore, HTMT results are stated below. Additionally, the threshold in HTMT is $<0.85$, which is the case in present results likewise, henceforth fulfilling the discriminant validity in similar manner.

Table 4. Discriminant Validity Fornell and Larcker criterion

\begin{tabular}{lllll}
\hline & CE & FE & IE & LGE \\
\hline CE & 0.844 & & & \\
FE & 0.559 & 0.858 & & \\
IE & 0.568 & 0.647 & 0.826 & \\
LGE & 0.472 & 0.535 & 0.540 & 0.775
\end{tabular}

Where CE is customer effectiveness, FE financial effectiveness, IE internal effectiveness, LGE learning and growth effectiveness

Table 5. Heterotrait-Monotrait Ratio (HTMT)

\begin{tabular}{llll}
\multicolumn{4}{c}{ Table 5. Heterotrait-Monotrait Ratio (HTMT) } \\
\hline & CE & FE & IE LGE \\
\hline CE & & & \\
FE & 0.602 & & \\
IE & 0.610 & 0.697 & \\
LGE & 0.483 & 0.562 & 0.567 \\
\hline
\end{tabular}

Where CE is customer effectiveness, FE financial effectiveness, IE internal effectiveness, LGE learning and growth effectiveness. The factor loadings and the items description in respective manner are presented below.

Table 6. Factor Loadings

\begin{tabular}{|c|c|c|}
\hline Items & Description & Loadings \\
\hline \multicolumn{3}{|c|}{ Customer Effectiveness } \\
\hline CE1 & $\begin{array}{l}\text { Customers satisfaction is an } \\
\text { important concern of zakat } \\
\text { institution }\end{array}$ & 0.882 \\
\hline CE2 & $\begin{array}{l}\text { Service quality of zakat } \\
\text { institution is continuously } \\
\text { improving }\end{array}$ & 0.890 \\
\hline CE3 & $\begin{array}{l}\text { Customer feedback is appreciated } \\
\text { by zakat institution }\end{array}$ & 0.885 \\
\hline CE4 & $\begin{array}{l}\text { Staffs of the zakat institution are } \\
\text { friendly }\end{array}$ & 0.735 \\
\hline CE5 & $\begin{array}{l}\text { Zakat institution is concerned } \\
\text { about recipients needs and } \\
\text { expectations }\end{array}$ & 0.875 \\
\hline CE6 & $\begin{array}{l}\text { Zakat institutions shows enough } \\
\text { respect towards clients }\end{array}$ & 0.787 \\
\hline \multicolumn{3}{|c|}{ Financial Effectiveness } \\
\hline FE1 & $\begin{array}{l}\text { Zakat institution is efficient in } \\
\text { utilising the fund }\end{array}$ & 0.814 \\
\hline FE2 & $\begin{array}{l}\text { Zakat institution tries best to } \\
\text { increase zakat collection from } \\
\text { different sources }\end{array}$ & 0.890 \\
\hline FE3 & $\begin{array}{l}\text { Zakat institution has } \\
\text { arrangement for providing } \\
\text { continuing assistance }\end{array}$ & 0.886 \\
\hline FE4 & $\begin{array}{l}\text { Zakat institutions encourage } \\
\text { financial bondage among peers }\end{array}$ & 0.853 \\
\hline FE5 & $\begin{array}{l}\text { Zakat institutions monitor the } \\
\text { recipients' usage of zakat fund }\end{array}$ & 0.854 \\
\hline
\end{tabular}


FE6

Zakat institutions does not

0.846

involve in risky investments

\section{Internal Effectiveness}

\begin{tabular}{|c|c|c|}
\hline IE1 & $\begin{array}{l}\text { The process to apply for zakat is } \\
\text { easy. }\end{array}$ & 0.648 \\
\hline IE2 & $\begin{array}{l}\text { Zakat institution prioritises the } \\
\text { stakeholders need }\end{array}$ & 0.819 \\
\hline IE3 & $\begin{array}{l}\text { Zakat collection mechanism of the } \\
\text { institution is efficient }\end{array}$ & 0.870 \\
\hline IE4 & $\begin{array}{l}\text { Zakat distribution mechanism of } \\
\text { the institution is good }\end{array}$ & 0.886 \\
\hline IE5 & $\begin{array}{l}\text { Zakat institution tries to find } \\
\text { innovative area to provide zakat }\end{array}$ & 0.858 \\
\hline IE6 & $\begin{array}{l}\text { Zakat institution gives special } \\
\text { care in case of emergency }\end{array}$ & 0.854 \\
\hline \multicolumn{3}{|c|}{ Learning \& Growth Effectiveness } \\
\hline LGE1 & $\begin{array}{l}\text { The financial knowledge of Staffs } \\
\text { of the zakat institution is good. }\end{array}$ & 0.789 \\
\hline LGE2 & $\begin{array}{l}\text { Employees are well trained about } \\
\text { related issues. }\end{array}$ & 0.832 \\
\hline LGE3 & $\begin{array}{l}\text { Zakat institutions provide } \\
\text { training to zakat recipients. }\end{array}$ & 0.756 \\
\hline LGE4 & $\begin{array}{l}\text { Zakat institutions provide } \\
\text { guidelines towards self-reliance. }\end{array}$ & 0.767 \\
\hline LGE5 & $\begin{array}{l}\text { The training and suggestions } \\
\text { provided are beneficial to } \\
\text { augment income. }\end{array}$ & 0.726 \\
\hline LGE6 & $\begin{array}{l}\text { The growth of the zakat } \\
\text { institution is satisfactory }\end{array}$ & 0.775 \\
\hline
\end{tabular}

Inter-item correlation matrix explains the internal consistency reliability to assess the instruments consistent results. A positive or higher correlation indicates a better correlation between constructs (Price et al., 2015). The inter-item correlation matrix is given below. The inter-item correlation is ranging from 0.4 to 0.64 which indicates a better and progressive correlation between constructs.

Table 7. Correlation between Variables

\begin{tabular}{clc}
\hline SL & Variables & 1 \\
\hline 1 & Financial Effectiveness & \\
2 & Customer Effectiveness & 0.558 \\
3 & Internal Effectiveness & 0.638 \\
4 & Learning \& Growth Effectiveness & 0.484 \\
\hline
\end{tabular}

SL stands for serial.

\section{Discussions, Implications, Recommendations and}

\section{Limitations}

The study aimed at understanding the perceptions of the zakat recipients, in order to empower them. The results prove that it's important to empower the zakat recipients in line with four effectiveness namely, the customer, internal, learning and growth, and the financial, and that has been duly acknowledged in previous studies. The respondents did put added emphasis on financial effectiveness which has higher cronbach's alpha, higher composite reliability and the higher AVE compared to the rest. Though all the results are above the minimum thresholds, but theoretically, it's important to work with all the four perspectives in cohesive manner to attain effective empowerment. In actual fact, all the perspectives are truly interlinked, and as the results having a progressive and greater correlation, therefore the study contributes positively to the understanding of the zakat empowerment and also fills the gap in terms of better understanding of the importance of these perspectives. These findings can help in zakat policies to understand its significance, and the emerging importance of 'constructive assessment' in the zakat sphere. Understanding from the point of customer perspectives, the financial, leaning, and internal all are equally important yardstick so as to work in cohesion to have a robust zakat empowerment regime. It's noteworthy to mention that, vast majority that are seeking help are married and in the able age bracket with bare minimum education and having merely three members in the family but still in hardship and seeking the necessary help, and that confirms the need for careful, crucial and enlightened empowerment of the recipients to look for a long-lasting solution and settlement, than just mere cash handouts, which are essentially a short term stop-gap measure.

The results show that almost equal number of male and female is in hardship category. Furthermore, in the able bodied age of 40 to 60 ranges, who might have already worked tirelessly for more than twenty years, but still not that contented with their income, for which they have to seek the bare assistance. So continuing with just cash hand-outs may not be wise, but empowering them with added skills may be a way through. Out of the total respondents, nearly forty plus percent have secondary education, which might substantiate the fact that they are the right recipients who should be given a thorough way out in terms of innovativeness and steward-ness in their own life. Another contrasting picture might be meticulously looked into, and that is, the household income less than a thousand RM per month is nearly 80 percent and zakat seeking families just mere RM 500 are nearly 80 percent likewise. Therefore it is rather evident that these people can be enabled and taken out of poverty brackets in gradual steps, if empowerment regimes initiate a proper groundbreaking way to make them self-reliant.

The study contributes to the zakat literature by initiating the understanding of the empowerment regime from the point of effectiveness of the broader performance issues. Though past research addressed isolatedly the empowerment and the performance, but understanding its minute linkages are still lacking in previous studies. The study attempted to understand the comprehensive reason on lack of empowerment and its repercussion from recipients' perspectives. The study further tried to remarkably assess the different aspects of performance issues, namely the financial, customer, internal and the learning obstacles in appreciating the growth and welfare and that from the recipients' point of view. Therefore, the study henee widens the understanding and provides a necessary suggestion to improve their status quo, as these recipients are the truest stakeholders, ${ }_{3}$ who need the assistance as they are in the receivingends.

0.482

The study portrays a number of important implications that can be a valuable guide for improving the empowering regime and strengthening the recipients' and stakeholders' satisfaction. First and foremost, customer's satisfaction is an important concern for all the stakeholders. From the response received, it is obvious that the service quality is improving, but the question still remains in matter to effectiveness and its dimensions, which might require a separate study altogether. Similarly the emphasis on the feedback process will make things even better, and that has been agreed by many respondents. On the demand of openness, more thorough training and skills enhancement is required, as it is 'the' pre-requisite for empowerment. Though the process of applying is getting easier, but from previous studies it was observed that not the full amount of collection is wholeheartedly distributed with the aim of empowerment. Although the growth of the zakat institution is getting better, but in order to strategically regain customer confidence, it is important to address the issues that recipients feel about the service and such. Hence institutions may need to be more proactive and innovative in order to retain the 'giving' customers so as to satisfy the 'receiving' ones (customers). The emphasis on monitoring the entire process has been repeatedly mentioned 
and that will ensure a better and long term solution towards empowerment.

On recommendations for future initiatives, it can be stated that though lots of effort are indeed initiated by the respective zakat institutions, but listening to grouses from the deprived grounds are paramount in making services even better and more cordial in nature and ensuring that in the nearest future. At occasions, the researchers did highlight the timeliness and other possible irregularities, which might be an obvious possibility in management scenario, but if the institutions follow an orderly BSC method, where entire management works as one entity, the chances of such tardiness may be lessened to a considerable extent. In efforts towards empowering the recipients, the main plan of action demands proper arrangements, timeliness and proper strategic execution and continuous monitoring of the entire process to ensure reduced rate of failure, which were seen in Malaysian zakat empowerment, as discussed earlier. It's important to note that the stakeholders concern, and their needs, requires more care and innovativeness in drive towards selfsufficiency and self-sustenance.

As with any academic assignment, the study is constrained with limitations and that encourages for more research in the future. Firstly the sample consists only from one state of Malaysia and that is Kedah. Secondly, only the performance from empowerment is studied here, and many other factors are though, equally significant to take into account, such as the sustainability of the recipients, but are left for future exploration. Thirdly, a cross-sectional study may not give a long term perspectives and furthermore, Malaysia is in a much better position than rest of the Muslim states, therefore the conditions in other territories may not be similar to that of Kedah, which in other terms may invalidate its generalizability. The study tried to understand only the performance through the empowerment of recipients ignoring the consequences on the recipients' sustainability. A forthcoming comprehensive and comparative study on this broader angle may provide more understanding on the implications and future directions.

\section{Contributions and Conclusion}

This study contributes towards better understanding of how assistance matters to wellbeing of the respondents and shapes the pattern of future sustainable development of the recipients. This research will assist decision makers to understand the factors that influences zakat recipients. The understanding of the stakeholders' perceptive perspectives is vital in making constructive and progressive on-going measures. So forthcoming research needs to comprehend the importance of stakeholders' perception and gear accordingly the future directions in regards to long term effective and sustainable zakat recipients' issues.

The academia, the practitioners, the governmental and nongovernmental agencies are expected to benefit from the findings of the study regarding the issues and shortcomings presented in intricate manner. It can be conjectured and positively anticipated that the authorities will identify the missing gaps, and appreciate to rectify the situation in orderly and proportionate mode to provide up-to-mark services to ensure long term solution to empowerment and other perennial issues. It's noticeable that zakat situation is improving in Malaysia and especially in Kedah, but further refining the overall performance will ease the task of empowerment and long term settlement to recipients' issues.

\section{ACKNOWLEDGMENTS}

The authors wish to express gratitude to Lembaga Zakat Negeri kedah (LZNK) for funding this project (S/0 Code: 14242). We also thanked those who have contributed towards the successful completion of this project.

\section{REFERENCES}

1. Abdelmawla, M. A. (2014). The Impacts of Zakat and Knowledge on Poverty Alleviation in Sudan: An Empirical Investigation (1990-2009). Journal of Economic Cooperation \& Development, 35(4), 61.

2. Abdulai, A. M., \& Shamshiry, E. (2014). Zakat as Policy Tool to Reduce Poverty and Improve Livelihoods. In Linking Sustainable Livelihoods to Natural Resources and Governance (pp. 161-171). Springer, Singapore.

3. Ab Rahman, A., Alias, M. H., \& Omar, S. M. N. S. (2012). Zakat institution in Malaysia: Problems and issues. Global Journal of Al-Thalaqah, 2(1), 35-42.

4. Adnan, N. S., Kamaluddi, A., \& Kasim, N. (2013). Intellectual Capital in Religious Organisations: Malaysian Zakat Institutions Perspective. Middle-East Journal of Scientific Research, 16(3), 368-377.

5. Afandi, M. A. (2019). Profitability Variables and Bank Size Effects on Corporate Zakat: Evidence from Indonesian Islamic Banks. International Journal of Zakat, 4(1), 55-66.

6. Ahmad, M., Dziegielewski, S. F., Tariq, I., \& Bhutta, A. Z. (2017). Zakat as a Social Safety Net: Assessing its Perception in a Less-Developed Rural District in Pakistan. Journal of Social Service Research, 43(3), 369-380.

7. Ahmad, N. H., \& Seet, P. S. (2009). Dissecting behaviours associated with business failure: A qualitative study of SME owners in Malaysia and Australia. Asian Social Science, 5(9), 98-104.

8. Ahmad, W. M. W., \& Mohamad, S. (2012). Classical jurists' view on the allocation of zakat: Is zakat investment allowed. Middle-East Journal of Scientific Research, 12(2), 195-203.

9. Ahmad, Z. (1991). Islam, poverty and income distribution: a discussion of the distinctive Islamic approach to eradication of poverty and achievement of an equitable distribution of income and wealth. Islamic Foundation UK.

10. Akhyar Adnan, M., \& Bakar, N. B. A. (2009). Accounting treatment for corporate zakat: a critical review. International Journal of Islamic and Middle Eastern Finance and Management, 2(1), 32-45. Al Qur'an. www.quran.com.

11. Bakar, M. H. A., \& Abd Ghani, A. H. (2011). Towards achieving the quality of life in the management of zakat distribution to the rightful recipients (the poor and needy). International Journal of Business and Social Science, 2(4).

12. Bakar, N. B. A. (2007). A zakat accounting standard (ZAS) for Malaysian companies. American Journal of Islamic Social Sciences, 24(4), 74.

13. Bakar, N. B. A., \& Rashid, H. M. A. (2010). Motivations of paying Zakat on income: Evidence from Malaysia. International Journal of Economics and Finance, 2(3), 76.

14. Bakar, N. R. A., \& Tajuddin, T. S. (2014). Performance management system in non-profit organisations: A case study in mosque AR, Proceeding of the International Conference on Masjid, Zakat and Waqf (IMAF 2014) (e-ISBN 978-967-13087-1-4). 1-2 December 2014, Kuala Lumpur, MALAYSIA.

15. Balanced Scorecard (n.d.). Balanced Scorecard Institute, https://www.balancedscorecard.org/.

16. Buckmaster, N. (1999). Associations between outcome measurement, accountability and learning for non-profit organisations. International Journal of Public Sector Management, 12(2), 186-197.

17. Campbell, D. T., \& Fiske, D. W. (1959). Convergent and discriminant validation by the multitrait-multimethod matrix. Psychological bulletin, 56(2), 81.

18. Clark, G. (2001). Pakistan's Zakat system: A policy model for developing countries as a means of redistributing income to the elderly poor. Social Thought, 20(3-4), 47-75.

19. Cohen, S., \& Vlismas, O. (2013). Analysing the relationship between intellectual capital and performance in local governments. Global Business and Economics Review. 
20. Fadilah, S., Lestari, R., \& Nurcholisah, K. (2016). Construction Of A Performance Assessment Model For Zakat Management Institutions. Mimbar: Jurnal Sosial dan Pembangunan, 32(2), 435-445.

21. Farouk, A. U., Md Idris, K., \& Saad, R. A. J. B. (2018). Moderating role of religiosity on zakat compliance behavior in Nigeria. International Journal of Islamic and Middle Eastern Finance and Management, 11(3), 357-373.

22. Farrukh, M. Z. (2016). The Need of Adequate Policies for Collection \& Distribution of Zakat. In The Name of Allah, The most Beneficent, The most Merciful, 47.

23. Ghazali, M.Z., Saad, R.A.J., and Wahab, M.S.A. (2016). A conceptual framework for examining trust towards zakat institution, International Journal of Economics and Financial Issues, 6(7S), pp. 98-102.

24. Gray, R., Bebbington, J., \& Collison, D. (2006). NGOs, civil society and accountability: making the people accountable to capital. Accounting, Auditing \& Accountability Journal, 19(3), 319-348.

25. Greiling, D. (2007). Trust and performance management in non-profit organizations. The Innovation Journal: Public Sector Innovation Journal, 12(3), 9.

26. Hair Jr, J. F., Sarstedt, M., Hopkins, L., \& Kuppelwieser, V. G. (2014). Partial least squares structural equation modeling (PLS-SEM): An emerging tool in business research. European Business Review, 26(2), 106-121.

27. Hassan, K. (2010). An Integrated Poverty Alleviation Model combining Zakat, Awqaf and Micro-finance, Seventh International Conference - The Tawhidi Epistemology: Zakat and Waqf Economy, Bangi, Malaysia.

28. Hassan, N. M. N. (1987). Zakat In Malaysia: Present And Future Status. IIUM Journal of Economics and Management, $1(1), 47-75$.

29. Hassan, N. M., Nor, A. H. B. M. \& Rom, N. A. M. (2012). Embracing Microfinance: Proposed Collaboration Between Zakat Institutions and Microfinance Institutions, 3rd International Conference on Business and Economic Research Proceeding, 12 - 13 March.

30. Hassan, R., \& Nasir, N. (2016). Prioritization of Zakat Distribution in Selangor and the Federal Territory of Malaysia: Are They Following the Right Distribution Principles According to Shariah?. Intellectual Discourse, 24.

31. Haron, N. H., Hassan, H., Jasni, N. S., \& Rahman, R. A. (2010). Zakat for asnafs' business by Lembaga zakat Selangor. Malaysian Accounting Review, 9(2), 123-138.

32. Henseler, J., Ringle, C. M., \& Sarstedt, M. (2015). A new criterion for assessing discriminant validity in variancebased structural equation modeling. Journal of the academy of marketing science, 43(1), 115-135.

33. Ibrahim, A., Abdullah, A. A., Kadir, M. R. B. A., \& AdwamWafa, S. M. G. W. S. (2012). Assessing Financial Reporting on adopting Business Zakat Guidelines on Malaysian Government Linked Companies. International Journal of Business and Social Science, 3(24).

34. Ibrahim, P., \& Ghazali, R. (2014). Zakah as an Islamic microfinancing mechanism to productive zakah recipients. Asian Economic and Financial Review, 4(1), 117.

35. Idris, A., \& Muhammad, S. O. (2013). Zakat as an instrument for poverty alleviation: a case study of Niger state zakat board, Niger state Nigeria, Paper Proceeding of the 5th Islamic Economics System Conference.

36. Jaffri Saad, R.A., Bidin, Z., Idris, K.Md., and Md Hussain, M.H. (2010). Factors that influenced the Business Zakah Compliance Behaviour [Faktor-faktor yang mempengaruhi Gelagat Kepatuhan Zakat Perniagaan], Jurnal Pengurusan, 30, pp. 49-61.

37. Lubis, M., Yaacob, N. I., Omar, Y., Dahlan, A., \& Rahman, A. (2011). Enhancement of zakat distribution management system: case study in Malaysia. In International
Management Conference 2011 Proceedings (pp. 1-10). University Sultan Zainal Abidin.

38. Kaleem, A., \& Ahmed, S. (2010). The Qur'an and poverty alleviation: A theoretical model for charity-based Islamic microfinance institutions. Nonprofit and Voluntary Sector Quarterly.

39. Kamaluddin, A., C.C. Huang, N.A. Ahmad Noruddin and Z. Baharum (2012). Measuring and Reporting Intellectual Capital of Malaysian Local Authorities. Paper presented at International Public Sector Conference (IPSC) 2012, Sabah, Malaysia.

40. Kaplan, R. S. (2001). Strategic performance measurement and management in nonprofit organizations. Nonprofit management and Leadership, 11(3), 353-370.

41. Kaplan, R. S., and Norton, D. P. (1992). The Balanced Scorecard: Measures That Drive Performance, Harvard Business Review, 71-79.

42. Kaplan, R. S., \& Norton, D. P. (1996). The balanced scorecard: translating strategy into action. Harvard Business Press.

43. Kaplan, R. S., \& Norton, D. P. (2000). Having Trouble with Your Strategy? Then Map It. harvard business review, 1.

44. Kaslam, S. (2009). The advancement of e-zakat for delivering better quality service and enhancing governance sphere of zakat institution in Malaysia. In Proceedings of World Zakat Forum.

45. Khairunnajah, K., Beik, I. S., \& Sartono, B. (2019). Proposing a Zakat Empowerment Program Using IDZ: Case from Cemplang Village, Bogor, Indonesia. International Journal of Zakat, 4(1), 45-54.

46. MacKrell, D., Houghton, L., \& Campbell, J. (2011). Just a notfor-profit: supporting sustainability with business intelligence in the not-for-profit sector. MCIS 2011 Proceedings. Paper 52.

47. Martinsons, M., Davison, R., \& Tse, D. (1999). The balanced scorecard: a foundation for the strategic management of information systems. Decision support systems, 25(1), 7188.

48. Masyita, D. (2012). Sustainable Islamic microfinance institutions in Indonesia: an exploration of demand \& supply factors and the role of waqf (Doctoral dissertation, Durham University).

49. Mohit, M. A., \& Nazyddah, N. (2011). Social housing programme of Selangor Zakat Board of Malaysia and housing satisfaction. Journal of Housing and the Built environment, 26(2), 143-164.

50. Mooraj, S., Oyon, D., \& Hostettler, D. (1999). The balanced scorecard: a necessary good or an unnecessary evil?. European Management Journal, 17(5), 481-491.

51. Muhammad, S. A., \& Saad, J. A. R. (2015). The Impact of Zakat Service Quality on Intention to Pay Zakat: Mediating Effect of trust on Zakat Institution. Education, Language and Social Sciences Education, Language and Social Sciences. https://doi. org/10.1017/CB0978110741.

52. Mujiatun, S. (2018). Model of Professional Zakat Management In Indonesia. International Journal of Economics, Business and Management Research, 2(04).

53. Mustafa, O. A. M., Har Sani Mohamad, M., \& Akhyar Adnan, M. (2013). Antecedents of zakat payers' trust in an emerging zakat sector: an exploratory study. Journal of Islamic Accounting and Business Research, 4(1), 4-25.

54. Nadzri, F. A. A., Rahman, A., \& Rashidah \& Omar, N. (2012). Zakat and Poverty Alleviation: Roles of Zakat Institutions in Malaysia. International Journal of Arts and Commerce, 1(7), 61-72.

55. Niven, P. R. (2002). Balanced scorecard step-by-step: Maximizing performance and maintaining results. John Wiley \& Sons. 
56. Noor, A. H. M., Rasool, M. S. A., Ali, R. M. Y. S. M., \& Rahman, R. A. (2015). Efficiency of Islamic institutions: Empirical evidence of zakat organizations' performance in Malaysia. Journal of Economics, Business and Management, 3(2), 282286.

57. Noor, R. M., \& Rashid, N. M. N. N. M. (2011, December). Zakat and tax reporting: Disclosures practices of Shariah compliance companies. In Humanities, Science and Engineering (CHUSER), 2011 IEEE Colloquium on (pp. 877882). IEEE.

58. Noor, A.M., \& Saad, R.A.J. (2016). The mediating effect of trust on the relationship between attitude and perceived service quality towards compliance behavior of zakah, International Journal of Economics and Financial Issues, 6(7Special Issue), pp. 27-31.

59. Othman, A., \& Noor, A. H. M. (2012). Role of zakat in minimizing economic inequalities among Muslim: A preliminary study on non recipients of zakat fund (NRZF). In 3 rd International Conference on Business and Economic Research (ICBER 2012), Bandung, Indonesia.

60. Othman, A., Noor, A. H. M., \& Salleh, A. M. (2015). An analysis relationship between social exclusion and nonrecipients asnaf of zakat fund (NRAZF). Australian Journal of Sustainable Business and Society, 1(2).

61. Othman, Y., Fisol, W.N.M., Yusuff, M.S.S. (2018). The Moderating Effect of Islamic Religiosity on Compliance Behavior of Income Zakat in Kedah, Malaysia. International Journal of Academic Research in Accounting, Finance and Management Sciences, 8(2), 281-286.

62. Pramanik, A. H. (1993). Development and distribution in islam. Pelanduk publications.

63. Price, P. C., Jhangiani, R., \& Chiang, I. C. A. (2015). Research methods in psychology, from web.

64. Raquib, A. (2011). Islamic Banking \& Zakat-An Alternative Approach to Poverty Reduction in Bangladesh. Journal of Islamic Economics, Banking and Finance, 7(2), 11-26.

65. Rachman, M. A., \& Salam, A. N. (2018). The Reinforcement of Zakat Management through Financial Technology Systems. International Journal of Zakat, 3(1), 57-69.

66. Richardson, G. (2004). Islamic law and Zakat Wacft Resources in Pakistan1. Islam and Social Policy, 156.

67. Saad, N., \& Abdullah, N. (2014). Is Zakat Capable of Alleviating Poverty?: An Analysis on the Distribution of Zakat Fund in Malaysia. Journal of Islamic Economics, Banking and Finance, 10(1), 69-95.

68. Saad, R. A. J., \& Farouk, A. U. (2019). A Comprehensive Review of Barriers to a Functional Zakat System in Nigeria: What Needs to be Done? International Journal of Ethics and Systems, 35(1), 24-42.

69. Saad, R.A.J., Sawandi, N. \& Muhammad, R. (2016). Zakat Surplus Funds Management. International Journal of Economics and Financial Issues. 6(7S), $171-176$.

70. Saad, R.A.J., \& Sawandi, N. (2016). Factors affecting and means of managing zakat surplus in Malaysia, Information (Japan), 19(18A), pp. 3137-3142.

71. Saad, R.A.J., Idris, K.M., Shaari, H., Sawandi, N., and Derashid, C. (2017). Governance of non-profit organizations: A case of zakat institutions in Malaysia, International Journal of Economic Research, 14(16), pp. 253-265.

72. Sahih Muslim. https://sunnah.com/muslim/33/24.

73. Said, J., Halim, H. A., Yusuf, S. N. S., \& Smith, M. (2014). A Comparative Study of Successful Male and Female Entrepreneurs: The Case of the Selangor Zakat Board (SZB).

74. Sawandi, N., Abdul Aziz, N.M., \& Saad, R.A.J. (2017). Zakat accountability practices: Case study of zakat institution AA International Journal of Economic Research, 14(16), pp. 223-232.

75. Sen, A. (1981). Poverty and famines: an essay on entitlement and deprivation. Oxford university press.
76. Senadjki, A., \& Sulaiman, J. (2015). An empirical study on the influence of Islamic values in poverty alleviation. Journal of Islamic Accounting and Business Research, 6(2), 222-243.

77. Sulaiman, H., Cob, Z. C., \& Ali, N. A. (2015). Big data maturity model for Malaysian zakat institutions to embark on big data initiatives. In Software Engineering and Computer Systems (ICSECS), 2015 4th International Conference on (pp. 61-66). IEEE.

78. Sulaiman, H., \& Jamil, N. (2014). Information security governance model to enhance zakat information management in Malaysian zakat institutions. In Information Technology and Multimedia (ICIMU), 2014 International Conference on (pp. 200-205). IEEE.

79. Sureshchandar, G. S., \& Leisten, R. (2005). Holistic scorecard: strategic performance measurement and management in the software industry. Measuring Business Excellence, 9(2), 12-29.

80. Taha, R., Ali, N. N. M., Embong, M. R., \& Nor, M. N. M. (2014). Developing a multidimensional performance of zakat collection system in East Coast Region. Procedia-Social and Behavioral Sciences, 164, 84-90.

81. Tlemsani, I., \& Matthews, R. (2013). Zakat and The Elimination of Poverty: New Perspectives. International Journal of Information Technology and Business Management, Vol.9, No. 1.

82. Van Der Zee, J. T. M., \& De Jong, B. (1999). Alignment is not enough: integrating business and information technology management with the balanced business scorecard. Journal of management information systems, 16(2), 137-158.

83. Wahab, N. Abd., Zainol, Z., \& Abu Bakar, M. (2017). Towards developing service quality index for zakat institutions. Journal of Islamic Accounting and Business Research, 8(3), 326-333.

84. Wahab, N. Abd., Zainol, Z., Bakar, M. A., Ibrahim, A. Z., \& Minhaj, N. (2016). Developing Service Quality Index for Zakat Institutions. International Journal of Economics and Financial Issues, 6(7S), 249-258.

85. Wahab, N. B. A. \& Abdul-Rahman, A. R. (2011). A Framework to Analyze the Efficiency \& Governance of Zakat Institutions, Journal of Islamic Accounting and Business Research, Vol. 2 No: 1, pp.43- 62.

86. Walker, D., \& Rowlinson, S. (2008). Procurement systems: a cross-industry project management perspective. Taylor \& Francis, Routledge.

87. Yap, P., \& Ferreira, A. (2010). The complex and multifaceted world of performance management in NGOs: a case study. Unpublished Dissertation, Monash University, Australia.

88. Yusoff, M. B. (2011). Zakat Expenditure, School Enrollment, and Economic Growth in Malaysia, International Journal of Business and Social Science, 2(6), pp. 175-81.

89. Yusoff, M., \& Densumite, S. (2012). Zakat distribution and growth in the federal territory of Malaysia. Journal of Economics and Behavioral Studies, 4(8), 449-456.

90. Yusoff, W. S. b. W. (2008). Modern Approach of Zakat as an Economic and Social Instrument for Poverty Alleviation and Stability of Ummah. Jurnal Ekonomi \& Studi Pembangunan, 9(1), 105-118.

91. Yusof, M.I.M. (2013). Lembaga Zakat Selangor's (LZS) Perspective, taken from web.

92. Zaenal, A. G. I. M. H., Shafiai, H., \& Ismail, A. G. (2014). Philanthrophy in Islam: A promise to Welfare Economics System. IRTI Working Paper Series.

93. Zahra, S. A., \& George, G. (2002). Absorptive capacity: A review, reconceptualization, and extension. Academy of management review, 27(2), 185-203.

94. Zainal, H., Abu Bakar, A., and Saad, R.A.J. (2016). Reputation, satisfaction of zakat distribution, and service quality as determinant of stakeholder trust in zakat institutions, 
International Journal of Economics and Financial Issues, 6(7S), pp. 72-76. [6]

95. Zakaria, M. (2014). The Influence of Human Needs in the Perspective of Maqasid al-Syari'ah on Zakat Distribution Effectiveness. Asian Social Science, 10(3), 165.

96. Zsolnai, L. (2015). The Promise of Spiritually-Based Management. In Post-Materialistic Business: Spiritual Value-Orientation in Renewing Management (pp. 21-45). Palgrave Macmillan UK.

97. Zulkifli, M. F. B., Taha, R. B., \& Embong, M. R. B. (2014). Establish a Balance Scorecard Approach to Enhance Zakat Distribution System in East Coast Region. MIICEMA 2014, 391. 